\title{
Critical analysis on inclusion of environmental studies in the elementary, secondary and senior secondary schools in Mizoram, India
}

\author{
H. Lalramnghinglova, ${ }^{1 *}$ Anil Pratap Singh, ${ }^{1}$ P.C. Lalrintluanga ${ }^{3}$ \\ ${ }^{1}$ Department of Environmental Science, Mizoram University, Tanhril 796004, India \\ ${ }^{2}$ State Council for Educational Research and Training, Chaltlang 796012, India
}

\begin{abstract}
Education is a process of development which includes three major activities, namely teaching, training and instruction. Environmental education is a process to promote the awareness and understanding of the environment, its relationship with man and his activities. It is also aimed at developing responsible actions necessary for preservation, conservation and improvement of the environment and its components. It has been introduced as a regular course in formal school education system in India following the directive of the Supreme Court of India. The present study aims at critically analyzing curriculum of environmental studies at primary, secondary and senior secondary level. The detailed analysis was done on the basis interactions with important stakeholders. In our study, we found that there is scarcity of qualified teachers to teach Environmental studies at each level. During interactions it was found that teachers have several environmental knowledge gaps and misconceptions about important environmental issues like about acid rain, ozone layer depletion and greenhouse effect. Our survey indicates that teachers hardly practice innovative methods to teach environment education. Most commonly used method is lecture. Field visits, practical, study tour and demonstrations are missing in many schools. It was also found that course content is not incremental; there is very often repetition of the topics. At college level, there is a need to focus more on environmental education and upgrade the course components. There should be both pre-service and in-service training for teachers to infuse emerging issues in course content. Such training should equip teachers for collecting and using relevant teaching materials to impart emerging issues. A few suggestions and recommendations are given based on critical analysis.
\end{abstract}

Keywords: Environmental education, education in Mizoram, critical analysis,

\section{Introduction}

\section{Definition of environmental science}

Environment comes from the French "environer" meaning "to surround, encircle, enclose, encompass". Environment can be defined as the set of conditions that surround an organism or living things or the complex of socio-cultural condition that affect an individual. Environmental Science is the systematic, scientific study of the environment in combination with living organisms including human beings. It is the field of science that studies the interactions of the physical, chemical, and biological components of the environment and also the relationships and effects of these components with the organisms in the environment. Environmental 
science focuses on the study of the relationships between the natural world and the organisms and their environments.

Environmental science is also referred to as an interdisciplinary field because it incorporates information and ideas from multiple disciplines. Within the natural sciences, such fields as biology, chemistry, and geology are included in environmental science. When most people think of environmental science, they think of these natural science aspects, but what makes environmental science such a complex and broad field is that it also includes fields from the social sciences and the humanities.

\section{Components of environmental science}

The environment consists of four components as explained under:

Atmosphere: The atmosphere implies the protective blanket of gases, surrounding the Earth: (a) It sustains life on the Earth. (b) It saves it from the hostile environment of outer space. (c) It absorbs most of the cosmic rays from outer space and a major portion of the electromagnetic radiation from the sun. (d) It transmits only here ultraviolet, visible, near infrared radiation (300 to $2500 \mathrm{~nm}$ ) and radio waves. $(0.14$ to $40 \mathrm{~m})$ while filtering out tissuedamaging ultraviolet waves below about $300 \mathrm{~nm}$. The atmosphere is composed of nitrogen and oxygen, and less amount of argon, carbon dioxide, and trace gases.

Hydrosphere: The hydrosphere comprises all types of water resources, such as oceans, seas, lakes, rivers, streams, reservoirs, polar ice-caps, glaciers, and ground water. (i) Nearly $97 \%$ of the Earth's water supply is in the oceans (ii) About $2 \%$ of the water resources is locked in the polar ice-caps and glaciers. (iii) Only about $1 \%$ is available as fresh surface water in the form of rivers, lakes, streams, and ground water that are fit to be used for human consumption and other uses.

Lithosphere: Lithosphere is the outer mantle of the solid earth. It consists of minerals occurring in the earth's crusts and the soil, e.g. minerals, organic matter, air and water.

Biosphere: Biosphere indicates the realm of living organisms, plants and animals and their interactions with environment, viz. atmosphere, hydrosphere and lithosphere.

\section{Reflection of environmental science in the Indian Constitution}

The then Prime Minister Mrs. Indira Gandhi, in the first International Conference on Human Environment at Stockholm in 1972, voiced deep concern about the degradation of the environment and eco-imbalances.
Article 21. "No person shall be deprived of his life or personal liberty except according to procedure established by law". Article 21 guarantees the right to life, a life of dignity, to be lived in a proper environment, free of danger of disease and infection. It is an essential fact that there exists a close link between life and environment. Right to life would become meaningless if there is no healthy environment.

Article 47. "The State shall regard the raising of the level of nutrition and the standard of living of its people and the improvement of public health as among its primary duties and, in particular, the State shall endeavour to bring about prohibition of the consumption except for medical purposes of intoxicating drinks and drugs which are injurious to health."

Article 48-A. "The State shall endeavor to protect and improve the environment and safeguard the forests and wildlife of the country."

Article 51-A (g). "It shall be the duty of every citizen of India to protect and improve the natural environment including forests, lakes, rivers and wildlife and to have compassion for living creatures."

\section{Supreme Court mandate on environmental science}

As we aware that environmental problem is a prominent issue in the $21^{\text {st }}$ century. Based on Article 21 of the Indian Constitution which guarantees each citizen the "right to life" necessarily includes the "right to a healthy environment," the Supreme Court of India enforced environmental studies as a compulsory subject at all levels of Indian education. The Supreme Court in its judgement delivered on 18 December 2003 directed the National Council for Educational Research and Training (NCERT) to prepare a model syllabus keeping in view the 1991 judgement to the states and educational agencies to introduce environment as a compulsory subject throughout the country in all classes in schools up to the higher secondary level from the academic year 2004-2005. The Attorney General opined that the University Grants Commission (UGC) would monitor the undergraduate and post graduate studies and take appropriate steps to prescribe a course on environment and making environment a compulsory subject at every level in college education. ${ }^{1}$ The National Policy on Education 1986 (modified in 1992) emphasized the need to create awareness of environmental concerns by integrating it in the educational process at all stages of education and for all sections of society. The NCERT asserted that school curriculum should highlight the measures for protection and care of the environment, prevention of pollution and conservation of energy. ${ }^{2}$ 


\section{Critical Analysis of Curricula of Schools and}

\section{Colleges}

The curricula of environmental studies in the school education in Mizoram is tri-furcated into (i) elementary education (ii) secondary education and (iii) senior secondary education.

\section{Elementary education}

The elementary education encompasses Class IVIII under the administration of Academic Authority of Elementary Education and the State Council of Educational Research and Training. ${ }^{3}$ SCERT prescribed separate text books on environmental studies from classes III-V and in classes I-II. Environmental education is incorporated in Class I-II in language and mathematics and also inter-woven with the child's immediate environment and the teacher as curriculum constructor.

Class I-II: EE is incorporated at this level through poetry, drawing, pictorial identification, project work etc. Child's immediate environment includes family and home, classroom and school, animals, birds, plants, food, water, play and recreation, cleanliness and good habits, keeping surroundings and classrooms clean, and taking care of plants and animals.

Class III-V: The text books contain collection of various themes and topics from socio-cultural and environmental aspects, e.g. personal cleanliness, recreation, local transport, clean environment avoiding spiting, littering, scratching walls, celebration of festivals, proper ways of disposal at homes and schools, fuel and electricity, car parks, gardens, monuments etc.

Class VI: The text book contains the resources and components of food, fiber and fabrics and living organisms and surroundings. Dependence of life on environment, protection and conservation of natural resources, appreciation of cultural heritage and respect and love for nature and right of others including animals and plants.

Class VII: The course covers water resources, water pollution and pollutants of water. The text book includes forests, wastewater, sanitation and hygiene and sewage disposal.

Class VIII: The text book includes pollution of air and water, greenhouses effect and global warming.

Each chapter of the above studies is supported by illustrations, multiple choice questions, short answer questions and practical activity to be done by teachers-led students. The textbook is based on activity-based Learning and is mandatory that the teacher guide the students in doing the project work and the activity.

\section{Secondary education}

The secondary and senior secondary textbooks are prescribed by the Academic Authority of Secondary and Senior Secondary Level, the Mizoram Board of School Education (MBSE). ${ }^{4}$

Class IX: The text book contains basic concept of cells and tissues, plant and animal kingdom; natural resources of the earth, air, water and soil, crop and animal husbandry, poultry and fish production, health and diseases and ozone layer.

Class X: The text book contains physics and chemistry, and incorporates nutrition, respiration, transpiration, nervous system and human hormones and plant movements; reproductive system in plants and human including HIV-AIDS; theory of hereditary and evolution, components of ecosystems, food chain and food web, fossil fuels, disposal of wastes and waste management and management of natural resources including energy, forests and wildlife, dams and rain water harvesting, coal and petroleum.

It is observed that there is a repetition on depletion and effects of ozone layer in both classes IX and X. It is, therefore, recommended that the portion of ozone layer in Class IX text book from pages $328 \& 329$ may be removed and the same content found in Class $X$ text book may be retained.

\section{Senior secondary education}

This section includes Class $\mathrm{XI}$ and XII. The curriculum comprises arts, science and commerce. Under science stream, the subjects of mathematics, physics, chemistry, computer science, home science and biology are offered. in the stream of biology, the basic concept of life sciences is prescribed in Class XI and the fundamentals of ecology and environment in Class XII. ${ }^{6,7}$

\section{Undergraduate course}

As per the requirement of University Grants Commission (UGC) and as directed by the Supreme Court, a separate paper of Environmental Studies is offered in the undergraduate courses as an elective paper for all subjects. Luckily, a separate Department of Environmental Science was established along with the Department of Biotechnology in Pachhunga University College, a constituent college of Mizoram University, in 2013.

\section{Bachelor of Education}

Recently, Bachelor of Education (B.Ed.) course was introduced in Mizoram University in 2018. However, nowhere in the syllabus are found the subject of environmental science. The contemporary subjects like physics, chemistry and mathematics can opt for mathematics in Pedagogy-I as well as physical 
science in Pedagogy-II. Likewise, chemistry, botany and zoology can opt for biological science in Pedagogy-I as well as physical science in PedagogyII under science/engineering/computer science/ agriculture. Like-wise, English/Mizo/Hindi and social science can opt for either English/Mizo/Hindi/ mathematics in Pedagogy-I and either social science or geography in Pedagogy-II under arts and commerce.

\section{Results and Discussion}

Based on the notification of the Supreme Court of India in 2006 and its direction to make the subject of Environmental Studies as one of the subjects in the curricula of schools and colleges, the course structure, the syllabi and the text books are examined critically and the following results, discussion and recommendations are given for future frame work of the curricula of environmental studies for Mizoram.

\section{Elementary education}

The SCERT Mizoram has followed the Supreme Court mandate and prescribed text books on Environmental Studies from Class III to VIII with full color illustrations, multiple questions and short answer questions and practical activity at the end of all chapters. It is mandatory to conduct on-the-spot verification in all schools whether the teachers-led students can do the activities provided in the text books or to what extend the teacher and students can do the exercise. In case some can do and some cannot, then emphasis should be given to teachers in the training programme. If majority of the schools cannot conduct practical activity, then it requires a revision to reduce the activity to a minimum level that can be done practically and effectively.

It would be desirable if software can be developed for life demonstration so that the children's attention will be captured and satisfy the inquisitee and all training undertaken by teacher training centres be done on hands-on activity as far as possible.

\section{Secondary education}

The content of environmental aspects in the text books of Class IX and X of the School Education can be considered very good. However, it is recommended that the contents and the text can be categorized into parts. For example, Part 1: Physics. Part 2: Chemistry. Part 3: Biology. Part 4: Environmental Science or Environmental Studies as separate section.

Duplication or repetition on ozone layer/ depletion and its effects in both Class IX and $X$ be removed from Class IX text book from pages 328 \& 329 and the same may be retained in Class X only.

\section{Senior secondary education}

Separate textbooks for physics, chemistry, geography, biology, etc. were prescribed by NCERT. The present textbooks are recommendable in Class $\mathrm{XI}$ and XII in all science disciplines following the National Curriculum Framework, 2005.

As reviewed all the textbooks and curricula mentioned above, and as far as practicable, it is recommended that all plants, animals, mountains, rivers, lakes etc. may be given the local or regional names with both scientific and local nomenclature. And, as most of the entrance examinations for higher studies is based on NCERT text books, it would be wise to prescribe NCERT text books for all others rather than other publisher(s).

\section{Bachelor of Education}

For Bachelor of Education being a compulsory qualification for school teachers, and environmental studies mandatory in the curriculum, it is recommended that physical science/environmental studies be included in Pedagogy-II as an optional subject under science/engineering/computer science/agriculture, as that of English/Mizo/Hindi and social sciences can opt either social science or geography in Pedagogy-II under arts and commerce.

\section{Future plan for environmental studies}

1. Recruitment rules of science teachers: The existing recruitment rules (RR) of primary school teacher demands minimum qualification of Class XII standard having $45 \%$ (ST) score with D.El.Ed degree or its equivalent two-year course. In this regard the recruitment of teachers could be made on subjectbasis demand. As of now, teachers having science background are insufficient in number to fill all the positions, so there is a lack of transaction of basics of science in the classroom teaching-learning process. Same teachers goes to the middle school section that the teacher having arts background need to teach the science subject.

2. Innovation: As we all know that practical activities develop scientific temper in the learners, Environmental Science exhibition, painting competition organized every year needs to be popularized and made mandatory for schools to participate in the programme.

3. Teaching posts: Environmental Studies being compulsory at all levels of education, the posts of Environmental Science should be essentially considered amongst other subjects, the reason being that B.Sc. in Environmental Science (since 2016) and above are produced every year since 2013 onwards. 


\section{References}

1. Anonymous (2014). Environment and Pollution Control Curriculum for Schools in India. Indian Institute of Ecology and Environment, pp. 1-51.

2. National Curriculum Framework (2005). Department of Education in Science and Mathematics, National Council of Educational Research and Training, New Delhi, p. 1.

3. Anonymous (2017). Textbooks of Environmental Studies for Class III-VIII, NCERT. Pub. SCERT, Mizoram.
4. Anonymous (2018). Secondary Science 9 \& 10, MBSE, Mizoram. Arya Publishing Company, New Delhi.

5. Sarita Agarwal (2010). Biology, Textbook for Class XI (Rep. 2019), Mizoram Edition. Madhubun, Vikas Publishing House, Pvt. Ltd. Noida.

6. Sarita Agarwal (2011). A Textbook of Biology for Class XII (Rep. 2017), Mizoram Edition. Madhubun, Vikas Publishing House, Pvt. Ltd. Noida. 